\title{
CHANGES IN MANAGING PROJECTS DUE TO COVID-19 IN THE CZECH REPUBLIC
}

\author{
Lenka SMOLÍKOVÁ* \\ Department of Informatics, Faculty of Business and management, Brno University of Technology, \\ Kolejni 2906/4, 612 00, Brno, Czech Republic
}

Received 2 March 2021; accepted 1 April 2021

\begin{abstract}
Purpose - this paper investigates the changes in managing and leading the projects due to COVID-19 in the Czech Republic.

Research methodology - a literature review, qualitative analysis based on conducted interviews with project managers in the Czech Republic. The main research objective is to obtain best practices and lessons learned from project managers in the IT sector.

Findings - the findings are based on interviews with project managers and reflect the reality in the Czech Republic in the field of project management. It describes what the project teams and project managers had to face during the pandemic. Findings are derived from the research and presented at the end of the paper.

Research limitations - the limitation of this paper is related to the research location, which was in the Czech Republic. The author suggests to extend the sample of data and include other countries in future investigations.

Practical implications - findings provide recommendations for successful project management in the future projects.

Originality and value - can be found in the recommendations for companies and lessons learned that can be used in managing new projects.
\end{abstract}

Keywords: project, project manager, team, COVID-19, communication, project management.

JEL Classification: M00, M10, M19.

Conference topic: Contemporary Organizations Development Management.

\section{Introduction}

Nowadays, everything is accelerating more and more, and the technology used by humanity is behind the last few years have turned beyond recognition. There is a necessity associated with this rapid step implementation of changes, especially in the field of information technology. These changes help manage and successfully implement project management.

Project management is already an integral part of IT projects. It includes a complex of activities such as goal setting, scope, detailed planning, organization, implementation, management, and control. Thanks to this, it is possible to manage large and demanding projects with high efficiency and effectiveness. The use of project management tools and methods results in more successful projects.

Project management is the application of knowledge, skills, tools, and technologies to project activities to meet the requirements of the project (Svozilová, 2011).

There are currently two ways to manage projects. They are Waterfall model and Agile. These two types of management are usually practically impossible to find in their pure form and their mutual combination is much more common. The difficulties to determine which of these methodologies is better are related to the fact that each address different types of projects. Today, IT projects use more agile project management with the implementation of some tools of the Waterfall model. The agile approaches welcome changing requirements and aim at satisfying customer needs via iterative development cycles and co-design with customers and users (Bouwman et al., 2018).

Rapidly changing market conditions, new technologies, short time-to-market cycles, and many other factors of the social and business world influence how projects are managed (Thesing et al., 2021).

\footnotetext{
*E-mail: smolikova@fbm.vutbr.cz
} 
Every project and its implementation are influenced by the environment. The project environment represents a connection, where the project is implemented (Berkun, 2008). The project connection on the environment, whether positive or negative, is called the context of the project (Němec, 2002).

The environment analysis is conducted at the beginning of the project. During this analysis stakeholders are identified, project risks are estimated and etc.

The project environment is made up of external and internal factors that influence project. The project manager should consider forces from project environment and their impact on the project. External influences, affecting the project, include factors, such as: conomic, political, social, cultural, ecological, financial, legal, market conditions, consumer trends, organizational technological and etc. (Flannes \& Levin, 2001; Baranauskas et al., 2020).

Internal factors can be described as organizational culture (such as vision, mission, and values), quality standards, risk tolerance, project stakeholders, employees, existing project management in the company.

The aim of this paper is to reveal the best practices and lessons learned of project managers in the IT sector in the Czech Republic.

This article is divided into several subchapters: introduction, theoretical background, methodology, findings and and conclusion. The theoretical background is focused on defining the issue based on available literature, scientific articles, and analysis of the situation during the pandemic in the Czech Republic. The methodology part describes how the research was conducted, the questions included, the respondents selected and when the research took place. The findings contain the results of the research. These results are described in detail and explanations are added. An important aspect of this part are the recommendations, which are developed in line with the results. These recommendations could be useful for project managers, who attempt to manage their projects more efficiently and successfully.

\section{Theoretical background}

Modern companies, business and business systems are based almost exclusively on project management. For this reason, knowledge and skills in project management have become increasingly important recourse for every successful company (Vujović et al., 2020). Project management is combination of many different tools, methods, skills, and experience. Project success is evaluated according to the triangle of time, cost, and quality (Atkinson, 1999).

Project is a temporary endeavour, which is designed to produce a unique product, service or result with a defined beginning and satisfy the predetermined goals and objectives, which are typically related to the beneficial change or added value (Nokes, 2007). Success and failure of project is directly linked to the quality of the human resources, which are selected to execute the project and adopted hierarchical structure (Kalayathankal et al., 2021).

The project manager is considered to be pivotal in traditional projects and is responsible for managing, teams, team building, motivation, communication, decision making, planning, and coaching (Pettersen, 1991). The project manager is envisioned as a connection between teams and project stakeholders (Shastri et al., 2021). For this reason, staffing of the projects by including the managers who have the right competences is crucial aiming to achieve project goal, to maintain competitive advantage and to ensure that the organization's projects will achieve the expected performance (Summer et al., 2017; Korsakienè et al., 2020).

The members of the project team perform one of the most important roles to achieve the success of a given undertaking (Słoniec, 2015). The team includes individuals from different groups who have the knowledge of a specific topic or skills required to work in a team (Biskupek, 2016). The COVID-19 global pandemic sent workers home on a massive scale and forced almost everyone, overnight, to work into virtual team (Gilson et al., 2021). Following COVID-19 and the introduction of several social distancing measures, the majority of organisations depend on employees who can collaborate virtually, to accomplish routine tasks and projects (Zuofa \& Ochieng, 2021). Virtual project teams definitions focus on the following aspects: cultural diversity, dispersion, and technological support (Beise et al., 2007). For many reasons the management of virtual teams is different than managing employees in a traditional face-to-face office environment. Though some benefits of virtual work, such as better work-life balance by working from home, more efficient use of time gained by not commuting to the office, and increased access to the best talent that can be located anywhere are mentioned, some unique challenges, faced by virtual employees, remain (Newman \& Ford, 2020).

The World Health Organization (WHO) declared the coronavirus disease - 19 (COVID-19) as s public health emergency with a pandemic spread on March 11, 2020. As of June 20, 2020, more than 8525042 confirmed cases have been reported in 216 counties across the world (WHO, 2020).

In 2019, when projects were planned for 2020, it was not possible to assume that the COVID-19 pandemic would emerge in 2020. No risk analysis in the risk identification phase assumed that something similar could happen.

The emergence of a pandemic can be attributed to the external factors that affect not only the operations of the projects in the Czech Republic. Therefore, several projects were suspended, especially in the spring of 2020, and project management was replaced by crisis management. The majority of the project managers had to deal with several obstacles such as the transition of the entire project team to home office. 


\section{COVID-19 situation in the Czech Republic}

The COVID-19 has spread in the Czech Republic from Italy after four months it has appeared in China, in December 2019. The sequence of the pandemic is as follows (IDNES, 2021):

- On March 1, 2020, the first three cases appeared in the Czech Republic and individuals became infected abroad.

- On March 7, 2020, the first person was infected in the territory of the Czech Republic.

- On March 10, 2020, after the meeting of the State Security Council, all schools were closed. The majority of employees moved to the home office if the nature of the work allowed it.

- On March 12, 2020, The Government of the Czech Republic declared a state of emergency, closed restaurants, state borders, shops, and services. In mid-April 2020, the spring wave of the epidemic culminated.

- On May 18, 2020, the state of emergency ended. By the end of June, COVID-19 measures were gradually being relaxed. However, majority of employees in the IT sector stayed at home in the home office.

- On September 30, 2020, the ministers approved a declaration of a state of emergency at an extraordinary meeting.

- Field hospitals were built in October and November.

- Due to the increased spread of the disease, the Czech Republic has reached the top of the world rankings in the number of infected and deceased in November 2020.

- In December 2020, the measures were partially relaxed.

- In January 2021 the situation has worsened again and another emergency has been declared.

The development of the events has a significant impact on the economy and business in the Czech Republic. Although this fact has not been reflected in the values of unemployment (in October 2020, the Czech Statistical Office published information that the value of unemployment in the Czech Republic is $2.9 \%$ ), the economic situation is affected by the governmental subsidies and interventions in the Czech economy (Czech statistical office, 2021).

\section{Project management in the Czech Republic}

A survey conducted by IPMA in the Czech Republic before the COVID-19 pandemic showed that the biggest problems that threaten the success of the projects in the Czech Republic are related to human resources. These include insufficient qualifications and incompetence of the project team members or lack of capacity and overloading of the team members.

The project is a temporary endeavour, which is designed to produce a unique product, service or result with a defined beginning and to satisfy the predetermined goals and objectives to bring beneficial change or added value (Nokes, 2007). The success and failure of the project are directly linked to the quality of the human resources selected to execute the project and adopted hierarchical structure (Kalayathankal et al., 2021).

\section{Project management in the Czech Republic during COVID-19 pandemic}

The survey was conducted among foreign project managers who were asked to rate remote team management. What was the reason for this survey? The idea was related to the productivity. The survey entitled "Project Management 2020". The trends revealed fundamental differences between domestic and foreign managers. Among other things, the differences were indicated in the approaches to the remuneration, personnel policy, and especially to the management of the team at a distance. These aspects were assessed positively or neutrally by $60 \%$ of foreign project managers and $30 \%$ of local managers. The reluctance of local managers to accept the approach of home work is related to the main cause - lower productivity (ITBIZ, 2021). The COVID-19 pandemic has been affecting lives and work in the Czech Republic for over a year.

The pandemic has brought a lot of changes, but also new challenges and new trends. One of them is the transition of employees to the home office. This trend was significantly reflected in project management. Almost half of the interviewed managers from the Czech Republic and abroad recorded at least 50 percent increase of workload from home compared to the previous year.

The Czech company "Easy Software", which supplies its own software solutions for project management to 26 countries around the world, has addressed local and foreign project managers from more than 250 companies across different segments. The aim was to evaluate the last "COVID" year.

Only a third of local managers perceive team management positively or neutrally. Meanwhile, foreign managers perceive it twice as much - about 60 percent. Nine percent of local project managers evaluate the remote management of the team in a very positive way as compared to 22 percent of foreign managers.

In 2020, local project managers unexpectedly lost their contracts. Due to the last year's events, two thirds of foreign managers unexpectedly acquired new projects, most often in the amount of 10-25 percent of their project portfolio. 
The most frequent reaction of local project managers was the reduction of remuneration. The reduction of remuneration was three times more frequent in local project teams than in foreign teams. It is interesting that foreign managers almost twice more often responded by intensifying the training of their employees than local managers.

The company "Easy Software" addressed the managers of its customers' list, which includes 252 companies. These were local and foreign managers (especially from Germany, France, the UK, Italy, Spain, and Russia). Of these, 47 percent work in a company with up to 50 employees, 23 percent in companies with 50-250 employees, 13 percent in companies with 250-1000 people and 17 percent work in companies with more than 1,000 employees (Lidovky, 2021).

\section{Methodology}

The qualitative research is more subjective than quantitative research. It focuses on understanding of human behaviour in the natural environment and through induction seeks to create a theory. The research focuses on a sample of respondents but gathers more detailed information (Bumberová, 2019).

The first phase of this research was a literature review and Internet research. The literature research focused on project management, project environment, COVID-19 and situation in the Czech Republic. The literature review provided the necessary input to paper.

The main research question was focused on gaining the best practices and lessons learned of the project managers in the IT industry in the Czech Republic.

The main goal of this research was to draw recommendations for the successful management of future projects based on interviews with selected project managers from IT companies.

The qualitative research was chosen for the purposes of this article. This research does not require to process a large amount of data, but to gain more detailed and subjective experience of IT project managers in the Czech Republic. The qualitative research was conducted in the form of guided interviews, the questions were provided to the respondents individually.

\section{Respondents}

30 respondents were contacted for the interviews. Unfortunately, due to the current situation related to the COVID-19 and the associated capacity of project managers only 15 project managers agreed to participate, of which 3 were women and 12 men. Gender and age did not play an important role in this survey. It was important that the project managers have at least 3 years of experience in managing IT projects so they can reflect their experience and insights during interviews. The interviews were anonymous so that the respondents felt comfortable and could openly talk about their projects. The research was conducted in 7.6.2020-15.12.2020.

\section{Questions}

During the interviews the respondents were first introduced to the aim of the research, and then they were asked questions, the essence of which was to obtain suitable data for research and aimed on the own experience of project managers.

The questions provided to the respondents are based on the research conducted by the company "Easy Software" and their compilation reflected the author's experience with project management and leadership.

The list of questions, provided to project managers during the interviews, is as follows:

1. What areas of projects were most affected by the Pandemic?

2. What changes did you have to deal with in the projects because of the COVID-19 pandemic?

3. What online communication tools have you decided to start using?

4. How do you think the functioning of the team has changed?

5. How do you think the pandemic will impact the project in the future?

Open data encoding was used to extract the data for interpretation.

\section{Findings}

1. What areas of projects were most affected by the Pandemic?

The majority of project managers agreed that the area of teamwork and team building were most affected. Another area is the setting of communication in the project and in the team. The last area mentioned was the reduction in staff performance, especially at the beginning of the Pandemic.

2. What changes did you have to deal with in the projects because of the COVID-19 pandemic?

There had to be a quick transition of team members to the home office, there was a change in the functioning of 
the team, changes in communication. From the beginning there were problems with the performance of individual members and there was also a problem with adherence to self-discipline.

3. What online communication tools have you decided to start using?

The project managers started using online tools such as: Slack, MS Teams, Zoom, Google Meets, Asana. According to the research, MS Teams and Slack are the most used of these tools.

4. How do you think the functioning of the team has changed?

The majority of the project managers agreed that the biggest changes in the functioning of the team can be seen in the lack of personal contact, the lack of personal team meetings and the lack of the informal team meetings. These issues had an impact on the already mentioned efficiency of the team.

5. How do you think the pandemic will impact the project in the future?

The answers of project managers were different to this question. One third of project managers said they thought that after the end of the pandemic, everything returns to normal (i.e., to the state before the pandemic), half of the project managers stated that the changes they implemented in the company's project management remain in the company. The rest of the project managers believe that the pandemic has not yet fully manifested itself in the projects and that it will be necessary to implement more extensive and serious changes in the projects than before.

The projects in 2020 demonstrated risks that no one expected in the planning phase of the project. The risks had to be addressed immediately and brought a few changes to the project management and the functioning of project teams.

Th changes in the working of the team were implemented. The teams had to switch to home office overnight. The team members were given a lot of freedom, but also hughe responsibility. Team members and project managers had to address importan issues: how to set up online team communication, how to share documents, how to replace personal project meetings, how to work with team and develop team spirit. At the same time, there was pressure to develop and work with self-discipline.

Home office had an impact on team performance and productivity. Therefore, project managers must contribute aiming to increase team performance and productivity. This may be related to the fact that remuneration for work was

reduced last year. The recommendation is to revise the motivation system, re-evaluate the motivational factors for individual team members and set up a control system at home office.

The changes in communication were the most significant. Team members were used to meet daily in the workplace and directly comment on issues in project meetings. However, these approaches have changed. The personal meetings were not possible, communication lacked non-verbal communication and a number of conflicts increased. The project managers started to use new online communication tools (e.g., Asana, MS Teams, Zoom, Google Meets and Slack).

There had to be a transition from project management to crisis management for majority of projects. The project crisis means that the project team cannot continue to manage the progress of the project by normal means. The project crisis is a situation where the success of the project is fundamentally endangered and extraordinary actions need to be implemented to ensure the success of the project. After resolving the crisis, the project team can take over the management of the project again, which will continue to manage according to the principles of project management.

\section{Recommendation for managing and leading projects in the future}

Based on the research and personal experience, the following recommendations were made for project managers and for project management:

- At the beginning of the project, always focus on the analysis of the internal and external environment.

- When planning a project, keep in mind the risk analysis. When identifying, rely on experience and best practices from past projects.

- Perform a detailed analysis of project management during the COVID-19 pandemic and create lessons learned for other projects.

- Set up a system of work for the home office and the functioning of a team that has the opportunity to meet only virtually.

- Increase pressure to implement agility in projects and to transform companies.

- See in the pandemic business opportunities, opportunities for the development of project team members and for the development of the project manager.

- Create an environment that supports the self-education of team members, the project manager and self-participation.

- Consider the possibility of a team transition to a system of so-called self-organizing teams.

- Involve technologies and online tools supporting project management more in project management.

- Learn to work with the priorities of the project and their content.

- Involve the customer more in the process of creating and managing projects.

- When managing projects, focus on creating value for the customer.

- Transition to digitization also in the fields that are currently preventing it. 


\section{Conclusions}

This article investigates a contemporary topic - the impact of the COVID-19 pandemic on project leadership and management in the Czech Republic.

For a more thorough understanding of project management issues, this article also contains a theoretical background for better understanding of the current situation. One of the main points of this article was the conducted qualitative research, which dealt with gaining knowledge about best practices and recommendations for project managers.

The most interesting and beneficial part of this article is the recommendations for project management and leadership in the future. These recommendations could help project managers with more effective project management and project team leadership not only in the Czech Republic. The implementation of the proposed recommendations should lead to and increase the success of the projects.

The author sees the possibilities of further research in the repetition and expansion of questions for project managers, after the Pandemic. Another future research possibility would be to compare the situation in project management after pandemic within neighboring countries, such as the Slovak Republic, Poland, and Germany.

\section{Disclosure statement}

This paper has no competing financial, professional, or personal interests from other parties.

\section{References}

Atkinson, R. (1999). Project management: cost, time and quality, two best guesses and a phenomenon, its time to accept other success criteria. International Journal of Project Management, 17(6), 337-342. https://doi.org/10.1016/S0263-7863(98)00069-6

Baranauskas, G., Raišienè, A. G., \& Korsakienè, R. (2020). Mapping the scientific research on mass customization domain: a critical review and bibliometric analysis. Journal of Risk and Financial Management, 13(9), 220-240. https://doi.org/10.3390/jrfm13090220

Beise, C., Neiderman, M., \& Herb, F. (2007). IT project managers' perceptions and use of virtual team technologies. IEEE Engineering Management Review, 35(4), 26. https://doi.org/10.1109/EMR.2007.4489946

Berkun, S. (2008). Making things happen: mastering project management (1st ed.) (410 p.). O’Reilly Media.

Biskupek, A. (2016). The research of stakeholder power impact on project implementation. Trends Economics and Management, 10(27), 9-19. https://doi.org/10.13164/trends.2016.27.9

Bouwman, H., Heikkila, J., Heikkila, M., Leopold, C., \& Haakek, T. (2018). Achieving agility using business model stress testing. Electronic Markets, 28(2), 149-162. https://doi.org/10.1007/s12525-016-0243-0

Bumberová, V. (2019). Výzkumné metody v rízení. Fakulta podnikatelská Brno.

Czech statistical office. (2020). https://www.czso.cz/.

Flannes, S. W., \& Levin, G. (2001). People skills for project managers. Management concepts. The United States of America.

Gilson, L., L., Costa, P., O’Neill, T., A., \& Maynard, M. T. (2021). Putting the "TEAM" back into virtual teams. Organizational Dynamics, 50(1), 100847. https://doi.org/10.1016/j.orgdyn.2021.100847

IDNES. (2021). Koronavirus. https://www.idnes.cz/koronavirus

ITBIZ. (2021). Řizeni projektů a produktivita v zahraničí a u nás. https://www.itbiz.cz/clanky/rizeni-projektu-a-produktivita-v-zahranici-a-u-nas- $/$

Kalayathankal, S.J., Kureethara, J. V., \& Narayanamoorthy, S. (2021). A modified fuzzy approach to project team selection. Soft Computing Letters, 3, 100012. https://doi.org/10.1016/j.socl.2021.100012

Korsakienè, R., Raišienė, A. G., Dinçer, H., Yüksel, S., \& Aleksejevec, V. (2020). Strategic mapping of eco-innovations and human factors: Business projects' success revisited. Strategic outlook for innovative work behaviours. Interdisciplinary and multidimensional perspectives (pp. 1-19). Springer International Publishing. https://doi.org/10.1007/978-3-030-50131-0_1

Lidovky. (2021). Průzkum Easy Software: Trendy projektového ř́zení 2020. https://www.lidovky.cz/pr/sdeleni-komercni/pruzkum-easy-software-trendy-projektoveho-rizeni-2020.A210202_105139_komercni-sdeleni_jedli

Newman, S. A., \& Ford, R. C. (2020). Five steps to leading your team in the virtual COVID-19 workplace. Organizational Dynamics, 50(1), 100802. https://doi.org/10.1016/j.orgdyn.2020.100802

Němec, V. (2002). Projektový management. Grada Publishing.

Nokes, S. (2007). The definitive guide to project management: the fast track to getting the job done on time and on budget (2nd ed.). Prentice Hall.

Pettersen, N. (1991). What do we know about the effective project manager? International Journal of Project Management, 9(2), 99-104. https://doi.org/10.1016/0263-7863(91)90068-7

Shastri,Y., Hoda, R., \& Amor, R. (2021). The role of the project manager in agile software development projects. Journal of Systems and Software, 173, 110871. https://doi.org/10.1016/j.jss.2020.110871

Słoniec, J. (2015). Project team management in the context of the development of project management science and new concepts of human resource management [Conference presentation] (pp. 301-315). XVIII Conference on Innovation in Management and Production Engineering. Opole. 
Summer, M., Bock, D., \& Giamartino, G. (2017). Exploring the linkage between the characteristics of IT project leaders and project success. Information Systems Management, 23(4), 21-33.

https://doi.org/10.1201/1078.10580530/46352.23.4.20060901/95112.6

Svozilová, A. (2011). Projektový management (2, aktualizované a doplněné vydání). Grada.

Thesing, T., Feldmann, C., \& Burchard, M. (2021). Agile versus Waterfall Project management: decision model for selecting the appropriate approach to a project. Procedia Computer Science, 181, 746-756. https://doi.org/10.1016/j.procs.2021.01.227

Vujović, V., Denić, N., Stevanović, V., Stevanović, M., Stojanović, J., Cao, Y., Alhammadi, Y., Jermsittiparsert, K., Van Le, H., Wakil, K., \& Radojkovic, I. (2020). Project planning and risk management as a success factor for IT projects in agricultural schools in Serbia. Technology in Society, 63, 101371. https://doi.org/10.1016/j.techsoc.2020.101371

World Health Organization. (2020). Coronavirus Disease (COVID-19) Outbreak. https://www.who.int/emergencies/diseases/novel-coronavirus-2019

Zuofa, T., \& Ochieng, E. G. (2021). Investigating barriers to project delivery using virtual teams. Procedia Computer Science, 181, 1083-1088. https://doi.org/10.1016/j.procs.2021.01.304 